\title{
Reducing Stress on Students through Traditional Music
}

\author{
N Alfiah ${ }^{1}$, A Meiza ${ }^{2}$ I N Hidayat ${ }^{3}$ \\ Universitas Islam Negeri Sunan Gunung Djati Bandung, Bandung, Indonesia ${ }^{1,2,3}$ \\ \{asti.meiza@uinsgd.ac.id ${ }^{2}$ \}
}

\begin{abstract}
The purpose of the research is to analyze stress reduction in students by giving traditional music (Cianjuran). The research method used quasiexperimental, control group design with pre-test and post-test data. The subjects of this research are 30 psychology students in a university in Bandung, Indonesia. In this study, the researchers used Subjective Units Distress Scale (SUDS) and adapted the Student-Life Stress Inventory from Gandzella. From a descriptive analysis, the result shows that Cianjuran music treatment can decrease the stress level.
\end{abstract}

Keywords: Stress, Cianjuran Music, Quasi-Experimental, (SUDS)

\section{Introduction}

Stress is an important problem that can affect an individual's mental health. Therefore proper action is needed to reduce stress levels. Individual vulnerability to physical/psychological disorders depends on the tendency of interactions with factors that cause disruption, and the amount of stress experienced [1]. Stress can be experienced by all humans, like students. Students are vulnerable to physical/psychological disorders because each semester has demands and pressures in the academic field, this will be a stressor which the body responds to as stress.

Some studies of stress and disorders experienced by stress sufferers show that this important variable is examined further. Moreover, efforts to reduce stress levels through various techniques and methods. Stress can affect memory, that is, when stress hormones are produced in very high doses, it will slow down the process of remembering the tasks that have been studied [2].

Data from the Basic Health Research (RISKESDAS) Ministry of Health in 2013 showed that of 703,946 adolescents aged $>15$ years, $6.0 \%$ (37,728 people) experienced emotional, mental disorders. This disorder is a term similar to distress psychology. This condition is a condition that indicates someone is experiencing psychological changes [3]. Students are the next generation, so research on stress among students is important because it is related to the mental health of the nation's successors.

Several methods have been carried out to reduce stress, such as pharmacological, behavioral, cognitive approaches, meditation, hypnosis, and music [4]. This study will examine the use of music as a stress-reducing medium. Music usually contains elements of rhythm, melody, harmony, and color of sound. In music also known as instrument terms, tones, chords, and compositions [5].

Music as a therapy has been done since the 18th century. In America music was used as therapy during World War I which was initially used in hospitals to treat trauma for veterans. 
In Indonesia, the musical prospects have not been seen from the aspect of benefits, because it functions only as entertainment [6]. Music therapy is defined as a therapeutic activity using music as a medium to repair, maintain, and develop the mental, physical, and emotional health [6].

Research related to traditional music namely classical Mozart music and traditional Javanese gamelan can reduce labor pain when one active phase is nulliparous, and there is no difference between the two types of music [7]. This study examines the influence of traditional music Cianjuran to reduce stress levels in students.

\section{Method}

The study used a quasi-experimental type method with a control group design with dependent pre-test and post-test sample designs[8] The population is the 6th-semester psychology students, totaling 125 people. Thirty students were willing to participate. According to Gay and Diehl, sample size depends on the type of research, in experimental research, the minimum sample size is 15 subjects per group. A total of 30 subjects consisted of 15 subjects in each group. In the implementation, two subjects resigned so that the number in the control group became 13 people.

The experiment occurred for three days. The subject is given the same situation, namely working on the task as a form of the stressor. The first day of the addition and multiplication task is within 10 minutes. The second day is the task of analyzing English articles in 7 minutes. The third day of memorizing the names of psychological disorders within 5 minutes ends the question with about 3 minutes. In the experimental group after being given the next assignment, Cianjuran music was played. The measuring instrument uses Student-Life Stress Inventory (SSI) and Subjective Units Distress Scale (SUDS) from Wolpe [9].

\section{Result and discussion}

The results of the study in the form of Subjective Units Distress Scale measurements are presented in Table 1 .

Table 1. SUDS scores in a three-day experiment

\begin{tabular}{|c|c|c|c|c|c|c|c|}
\hline \multirow{2}{*}{$\begin{array}{l}\text { Experimental } \\
\text { Group }\end{array}$} & \multicolumn{3}{|c|}{ Day } & \multirow{2}{*}{$\begin{array}{l}\text { Control } \\
\text { Group }\end{array}$} & \multicolumn{3}{|c|}{ Day } \\
\hline & 1 & 2 & 3 & & 1 & 2 & 3 \\
\hline 1 & 3 & 1 & 1 & 16 & 3 & 3 & 4 \\
\hline 2 & 6 & 0 & 0 & 17 & 2 & 0 & 0 \\
\hline 3 & 4 & 3 & 1 & 18 & 5 & 5 & 7 \\
\hline 4 & 1 & 3 & 2 & 19 & 4 & 6 & 3 \\
\hline 5 & 5 & 4 & 3 & 20 & 5 & 4 & 5 \\
\hline 6 & 3 & 1 & 0 & 21 & 7 & 3 & 1 \\
\hline 7 & 6 & 0 & 0 & 22 & 6 & 5 & 4 \\
\hline 8 & 0 & 0 & 0 & 23 & 1 & 3 & 3 \\
\hline 9 & 4 & 3 & 0 & 24 & 3 & 3 & 3 \\
\hline 10 & 5 & 1 & 1 & 25 & 5 & 7 & 7 \\
\hline 11 & 1 & 3 & 5 & 26 & 1 & 2 & 3 \\
\hline 12 & 3 & 3 & 3 & 27 & 3 & 6 & 6 \\
\hline
\end{tabular}




\begin{tabular}{llllllll}
13 & 5 & 0 & 0 & 28 & 3 & 3 & 8 \\
14 & 10 & 2 & 1 & & & & \\
15 & 4 & 4 & 3 & & & & \\
\hline
\end{tabular}

The results of observations and measurements of the profile of experimental subjects are presented in Figure 1 and Figure 2. Figure 1 presents a profile of stress levels as measured by SUDS which shows that giving Cianjuran music can reduce stress levels in most subjects, 11 out of 15 people. Whereas in the other four subjects, the stress levels remained low and stress levels increased. While the graph in Figure 2 shows that the subjects are acting as a control, shows a diverse profile that is mostly up ( 8 people), constant ( 1 person), and down (4 people).

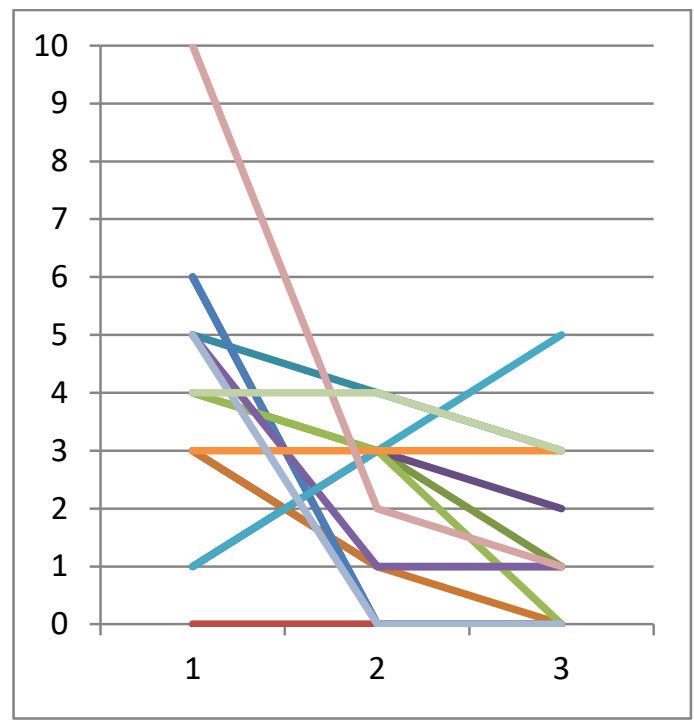

Figure 1. The profile of stress levels of experiment subject

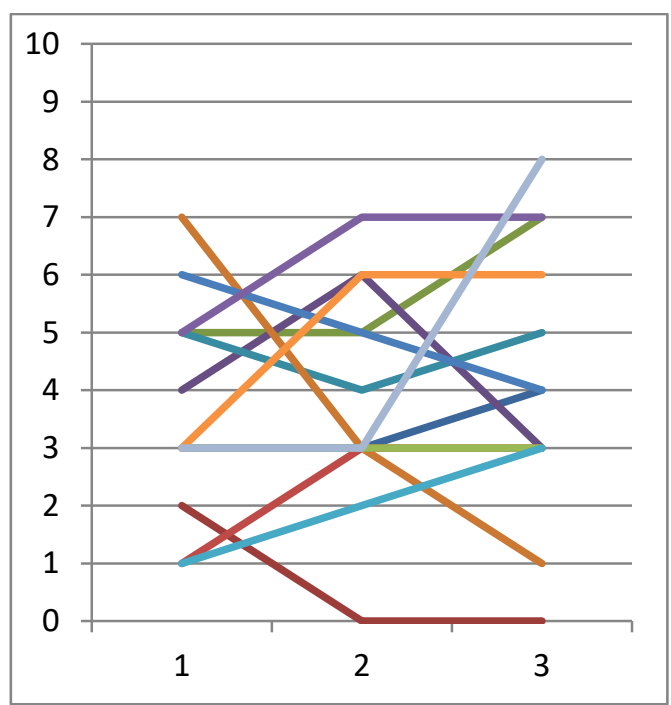

Figure 2. The profile of stress level of control subject

An overview of the stress level profile in the experimental group which showed a large decrease, whereas in the control group there was a general increase, this implies that suggestion music can reduce stress, even though the Mann-Whitney test results on SSI scores have not proven the same results $(.092>.05)$. The results of this study are in line with several previous studies, both related to the type of treatment in the form of music, as well as measured variables. Research Abdullah, Suryaningrum, and Prasetyaningrum (2013) who found the conclusion that Javanese music was able to reduce stress levels in students [10], as well as this study that could strengthen these results that traditional music with different types in this case music originating from Java West, namely Cianjuran music, also has a function as a therapy for stressful situations experienced by students.

The results of this study can also be compared with the research of Supriadi, Hutabarat, and Monica (2015) who found there were differences in the mean systolic and diastolic blood pressure in elderly individuals, before and after being given traditional Sundanese flute harp 
music therapy [11]. With media treatment music that is almost the same as the type of traditional music that is owned by Sundanese ethnicity, if the results of the study only measure the effect on physiological reactions in the form of blood pressure, this study has contributed by measuring its effect on psychological reactions in the form of decreased stress levels. Also, in this study, a task completion situation was created which was intended as a stressor for the subject so that treatment was an important part that could be measured.

Cianjuran music as a media treatment in this study, with the title song Gandrung Gunung without lyrics, has 50-70 hits per minute and is given in a volume of 60 decibels, can be assessed as showing therapeutic functions. As stated by Nilsson (2008) that music is used for therapeutics if it is without lyrics, a slow tempo, and a maximum volume of 60 decibels [12]. Puspita (2007) also said that music with a rhythm of approximately 60 beats per minute, (slow tempo) has a calming effect, including soft music that is effective in reducing the level of insomnia [13].

In this study, the measurement of stress uses two types of measuring instruments and different analytical methods, namely descriptive and inferential. SUDS is used to measure the level of stress felt by the subject by giving a score of 0-10 every time you finish working on a task intended as a stressor. Based on the three SUDS scores obtained profiles of stress levels of each subject. Regarding characteristics, SUDS is classified as a simple measuring instrument that functions to obtain information about the subject's self-assessment at the beginning of the treatment, monitor changes experienced and assessed the progress of the treatment process.

The profile of reducing stress levels in the experimental group, namely: first, subject 1 and 10 , on the first day of the high score while the next day decreased to a score of 1 . Both subjects had never listened to Cianjuran music, but subject 1 was accustomed to traditional arts, ranging from dances to songs. During giving treatment subject, 1 listened to Cianjuran music until it fell asleep, due to feeling calm, comfortable and relaxed. Changes from score 3 to score 1 on subject 1 can be interpreted that basically the task faced is enough to make him anxious or depressed, but he is still quite adaptive in completing it. The 'sleeping' response is possible because of the formation of changes in brain waves from beta conditions to alpha and even theta [6].

Second, subjects 2, 7, and 13 have the same pattern. On the first day, the score was high while the next day became 0 . The three subjects had never listened to Cianjuran music, especially subjects 2 who came from the Padang area. In all three subjects, it was seen more clearly how Cianjuran music played an important role in relieving feelings of anxiety or stress that had taken up enough of their energy.

Third, subjects 6 and 9 feel bored when they first listen to Cianjuran music, because the music sounds monotonous. The next day, the subject began to feel comfortable and imagine being in a rural area. Boredom as a negative emotional reaction when responding to Cianjuran music stimulation, can be assessed as spontaneous feelings that are still relatively reasonable because the results of their interpretations that consider music with a slow tempo are something monotonous and boring. Such interpretation also does not appear just like that but is based on previous experiences concerning interests or preferences for certain types or tempo of the music.

Fourth, 14 subjects from Lampung area, when they first listened to Cianjuran music the subject felt uncomfortable. The first day showed a score of 10 , which means the subject felt very depressed, frightened, anxious, and uncomfortable. However, the next day, the subject experienced a decrease in stress. This means that even though the music treatment is negatively experienced in the form of feeling uncomfortable because of the foreignness of the 
stimulus, this type of emotion is lighter than the feeling of dislike, so that feeling uncomfortable is easier tolerated by the individual because it is a natural feeling when accompanying the process of individual adjustment to a stimulus that is new or foreign to him.

SSI is a more comprehensive measurement tool, which functions to measure stress levels in students which includes two aspects, namely stressors (frustration, conflict, pressure, change, self-demand) and response (physiological, emotional, behavioral, cognitive assessment). Measuring stress levels based on SSI scores is certainly more adequate to ensure there is no decrease in stress. However, the results of inferential testing show that there is no influence of Cianjuran music in reducing stress levels, so this can be explained through several extraneous variables that are reinforced by the results of interviews and observations.

First, the use of Sundanese traditional music, namely Cianjuran music. It is possible that there is a subject who feels alien or is just listening for the first time so that it is less or not like the type of music. Even though they are willing to participate, they cannot be forced to like the music, so when there is a subject, there is a subject who wants to leave the room immediately because they feel uncomfortable.

In line with Djohan's opinion that the music tastes that are liked or disliked by the subject can cause various effects [14]. In subject 11 the level of stress increased because he admitted that he did not like traditional music, so when he was played by Cianjuran music the subject felt he wanted to rush out of the room. Psychologically, it can be explained that music stimulation as a treatment, when lived negatively through feelings of dislike, the original target that the music was intended to reduce stress was the opposite, it could be experienced as another stressor that helped increase the stressful situation at that time.

Second, it is related to motivation which is an internal and external impulse that causes an individual to approach something or keep away from something because of discomfort [2]. This research took place for 3 consecutive days, where the desires of the subjects in participating in this study were certainly different. For example, if the subject feels uncomfortable because this study interferes with resting hours, the subject will feel compelled so that he does not take the research process seriously.

Third, body condition factors such as fatigue. The experiment took place from 11.30-13.00 WIB after the lecture. This can cause the subject to do the task in a hurry and not focus because then they will take the lecture again.

Fourth, mortality threat namely changes in the number of individuals during the pre-test and post-test. In this case, a subject who has the willingness to take part in the whole series of studies has been chosen. However, on the second day, two subjects in the control group were absent for reasons of illness and urgent interests. This reduced number of subjects also influences the representative aspects of the statistically recommended number.

\section{Conclusion}

The results of the descriptive analysis showed a profile of decreasing stress levels in most of the experimental subjects. The important role of Cianjuran's music for student subjects has reinforced the existence of the music in carrying out therapeutic functions for stressful situations. This therapeutic function can be achieved through several criteria, namely music without lyrics, 50-70 minutes per minute and volume 60 decibels. Future research can compare the effects of traditional music treatment with the type of music that is favored or other types of music, and determine treatment in the right amount of time, choose subjects with more homogeneous characteristics. Moreover, further study could use Electro Encephalo 
Graphy (EEG) equipment to obtain accurate results related to brain activity as an effect of the treatment of music given.

\section{References}

[1] E. P. Sarafino and T. W. Smith, Health psychology: Biopsychosocial interactions, 7th ed. New Jersey: John Wiley \& Sons, 2014.

[2] C. Wade and C. Tavris, Psikologi. Jakarta: Erlangga, 2007.

[3] Badan Penelitian dan Pengembangan Kesehatan Kementerian Kesehatan RI, "Riset Kesehatan Dasar," Badan Penelitian dan Pengembangan Kesehatan Kementerian Kesehatan RI, Jakarta, 2013.

[4] A. Primadita, Efektivitas Intervensi Terapi Musik Klasik Terhadap Stress Dalam Menyusun Skripsi pada Mahasiswa PSIK Undip Semarang. Semarang: Universitas Diponegoro, 2012.

[5] A. Syukur, A. Sobirin, and A. Riyadh, Ensiklopedia Umum untuk Pelajar. Jakarta: Ichtiar Baru Van Hoeve, 2008.

[6] Djohan, Terapi Musik: Teori dan Aplikasi. Yogjakarta: Galang Pers, 2006.

[7] N. S. Oktavia, S. Gandamiharja, and I. B. Akbar, "Perbandingan Efek Musik Klasik Mozart dan Musik Tradisional Gamelan Jawa terhadap Pengurangan Nyeri Persalinan Kala I Fase Aktif pada Nulipara," Maj. Kedokt. Bandung, vol. 45, no. 4, pp. 218-225, Dec. 2013.

[8] T. D. Cook, D. T. Campbell, and W. R. Shadish, Experimental and quasiexperimental designs for generalized causal inference. Boston: Houghton Mifflin company, 2002.

[9] D. L. Molin, "A User Guide to Using the SUDS Scale to Measuring the Intensity of Feelings," 2015.

[10] J. Abdullah, C. Suryaningrum, and S. Prasetyaningrum, "Musik Jawa untuk Mereduksi Stress pada Mahasiswa," J. Interv. Psikol., vol. 5, no. 2, pp. 89-101, Dec. 2013.

[11] D. Supriadi, E. Hutabarat, and V. Monica, "Pengaruh Terapi Musik Tradisional Kecapi Suling Sunda Terhadap Tekanan Darah Pada Lansia Dengan Hipertensi,” J. Sk. Keperawatan, vol. 1, no. 2, pp. 29-35, 2015.

[12] U. Nilsson, "The Anxiety- and Pain-Reducing Effects of Music Interventions: A Systematic Review," AORN J., vol. 87, no. 4, pp. 780-807, Apr. 2008.

[13] A.S. Puspita, "Terapi Musik Lembut Terhadap Penurunan Insomnia Dewasa Awal." Universitas Muhammadiyah, Malang, 2007. 